\title{
Preliminary re-evaluation of probabilistic seismic hazard assessment in Chile: from Arica to Taitao Peninsula
}

\author{
F. Leyton ${ }^{1}$, S. Ruiz ${ }^{2}$, and S. A. Sepúlveda ${ }^{2}$ \\ ${ }^{1}$ Depto. Ciencias Aplicadas, Universidad de Talca, Curicó, Chile \\ ${ }^{2}$ Depto. Geología, Universidad de Chile, Santiago, Chile
}

Received: 30 April 2009 - Revised: 30 September 2009 - Accepted: 2 October 2009 - Published: 14 December 2009

\begin{abstract}
Chile is one of the most seismically active countries in the world; indeed, having witnessed very large earthquakes associated with high horizontal peak ground accelerations, the use of probabilistic hazard assessment is an important tool in any decision-making. In the present study, we review all the available information to improve the estimation of the probabilistic seismic hazard caused by two main sources: shallow interplate, thrust earthquakes and intermediate depth, intraplate earthquakes. Using previously defined seismic zones, we compute Gutenberg-Richter laws and, along with appropriate attenuation laws, revaluate the probabilistic seismic hazard assessments in Chile. We obtain expected horizontal peak ground acceleration with a $10 \%$ of probability of being exceeded in 50 years, reaching from $0.6 \mathrm{~g}$ up $1.0 \mathrm{~g}$ in the coast and between $0.4 \mathrm{~g}$ and $0.6 \mathrm{~g}$ towards the Andes Mountains, with larger values in Northern part of the country. The present study improves our knowledge of geological hazards in Chile, enabling the mitigation of important human and material losses due to large earthquakes in the future.
\end{abstract}

\section{Introduction}

Chile is one of the most seismically active countries in the world (Scholz, 2002), mostly due to its location on the Pacific Ring of Fire. Indeed, from $18^{\circ} \mathrm{S}$ to $45^{\circ} \mathrm{S}$, Chile is placed on the contact between the oceanic Nazca Plate and the continental South American Plate, with an estimated convergence rate of 6-7 cm/yr (Khazaradze and Klotz, 2003). Within this context, several researchers have put in evidence two main kind of seismogenic sources: interplate, thrust events, with epicentres located along the coast, depths ranging between

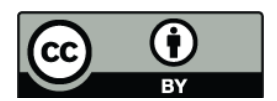

Correspondence to: F. Leyton (fleyton@utalca.cl)
15 and $50 \mathrm{~km}$ (for a review, see Barrientos, 2007), and a second group of earthquakes located inside the subducting Nazca plate with continental epicentres of intermediate depth (greater than $50 \mathrm{~km}$ ), known as intraplate or inslab events (Kausel and Campos, 1992; Barrientos, 2007). Similar classification has also been found in Mexico's subduction zone (Singh et al., 2000; García et al., 2005) and other subduction zones world-wide (for a review, see Astiz et al., 1988). Each one of these seismogenic sources have particular properties, producing a different effect on structures; hence, each one requires a special analysis (Saragoni et al., 2004; Astroza et al., 2002, 2005; Leyton et al., 2009b). For example, Astroza et al. (2002) showed that intraplate earthquakes reached intensities of almost two points in modified Mercalli Intensity larger than interplate events in the epicentral region. More over, Leyton et al. (2009a), using recordings at regional distances, found clear differences between both kinds of events on their source characteristics (such as seismic moment, corner frequency, seismic energy, and apparent stress drop). Furthermore, several studies have shown important seismotectonic differences between different plate contacts (Uyeda and Kanamori, 1979; Ruff and Kanamori, 1980; Kanamori, 1986); clearly reflected on the different seismic demands, making mandatory specific studies for each particular area.

Seismic hazard assessments in Chile have been improving along with our knowledge of the seismotectonics in the region. Greve (1948) developed the first seismic hazard study in Chile, defining seismic response coefficients for different regions in the country. Later, Lomnitz (1969) made the first probabilistic calculations, defining the first seismic hazard map by considering only earthquakes with magnitudes $M_{S}$ larger than 7.5 and assuming that temporal occurrence of an earthquake followed a Poisson distribution. Afterwards, a series of studies addressed the issue of seismic hazard assessments for whole Chile using the probabilistic approach (Barrientos, 1980; Villablanca and Riddell, 1985; Martin,

Published by Copernicus Publications on behalf of the European Geosciences Union. 
1990; Algermissen et al., 1992; Alvarez et al., 2002), as well as regional studies (Romanoff, 1999; Leyton et al., 2009b); most of these works have included all the seismicity reported, without clearly separating the effect of the different seismogenic sources.

The probabilistic approach used in most of these studies follow the methodology described by Algermissen and Perkins (1976), based on the theoretical computations made by Cornell (1968). This procedure basically defines the main seismogenic sources present in the region, describing them in seismic productivity (Gutenberg \& Richter laws) and attenuation functions; then, by assuming that earthquakes occurrence follow a Poisson distribution, the probability of exceeding certain horizontal peak ground acceleration (PGA) over a time period is defined. The results obtained from this procedure combine the information from all seismogenic sources defined in the region, giving an estimation of the complete seismic hazard in the area. This methodology include several assumptions worth discussing, such as: earthquake occurrence follow a Poisson process with a GutenbergRichter distribution of magnitudes, definition of specific seismic zones, considering the seismicity as a stationary process, etc. The Poisson process assumption have been previously discussed (Musson et al., 2005), and shown that the collective effect of a number of non-Poissonian processes approximates to Poissonian behaviour (Khintchine, 1960); even more, Cornell and Winterstein (1988) showed that the Poisson assumption leads only to small errors. On the other hand, recently new models have been proposed for the recurrence of earthquakes (Schwartz and Coppersmith, 1984; Wu et al., 1995; Mattews et al., 2002), and their application to an Andean context should be discussed further (see, for example, Wesnousky, 1994). As discussed in Musson et al. (2005), the assumption of stationarity process can be justified by the geological principle of uniformitarism, enabling the estimation of parameters from seismic catalogues and paleosismic data. Nevertheless, several authors have pointed out limitations of the probabilistic seismic hazard assessment, for example, the use of probabilities on a phenomenon (the seismic cycle) with few observations (Castaños and Lomnitz, 2002) and the fact that ground motions derived from probabilistic assessments cannot be related to a specific earthquake (Wang et al., 2003).

Despite these observations, in the present study, aimed to obtain a preliminary assessment of seismic hazard in Chile, we use the probabilistic approach considering the two main seismogenic sources: interplate, thrust earthquakes and intraplate, intermediate depth earthquakes. Firstly, we combine information from different catalogues and define linear relations between different magnitudes used in Chile and surface magnitude $\left(M_{S}\right)$, homogenizing all the information. Afterwards, using an updated version of the seismogenic zones defined by Martin (1990), we compute the Gutenberg-Richter relations for both kinds of sources. Finally, using appropriate attenuation relationships (specifically defined for Chile), we compute the PGA that has $10 \%$ of probability of being exceeded on 50 years (equivalent to a return period of 475 years).

The results presented here represent only first order computations because, in certain areas, there is the influence of a third seismogenic zone, corresponding to crustal earthquakes related to deformation in the crust, as considered in previous works (Martin, 1990; Algermissen et al., 1992; Romanoff, 1999; Leyton et al., 2009b). Nevertheless, the results obtained in this study will help improve our understanding of the seismic hazard in Chile, enabling a better prevention of human and material losses produced by large earthquakes.

\section{Methodology}

In the present study, we use the probabilistic approach to estimate the seismic hazard in Chile (from $18^{\circ} \mathrm{S}$ to $45^{\circ} \mathrm{S}$ ) considering only two main seismogenic sources: interplate, thrust earthquakes and intermediate depth, intraplate earthquakes. We use the definition of seismogenic sources made by Martin (1990) that consider the separation of interplate, thrust and intermediate depth, intraplate earthquakes (see Fig. 2); updated with improved descriptions of the plate contact reported by Gudmundsson and Sambridge (1998).

In this work, we consider the information from three different seismic catalogues: SISRA (Askew and Algermissen, 1985), the National Earthquake Information Center (NEIC, 2009), and the International Seismological Centre (ISC, 2001). The SISRA catalogue considers the long historical information available for Chile up to 1982 (recently updated to 2005, see Araya, 2007), the ISC catalogue extends from 1906 until January 2007, and the NEIC catalogue includes from 1973 to December 2008. In order to homogenize the information, we compute relations between all used magnitudes (body wave magnitude mb, local magnitude $M_{L}$, or moment magnitude $M_{w}$ ) and surface magnitude $\left(M_{s}\right)$, as done in previous studies (Barrientos, 1980; Algermissen et al., 1992; Leyton et al., 2009b). Firstly, we searched in the different catalogues for all events that presented $M_{s}$ and other magnitude (either mb, $M_{w}$ or $M_{L}$ ); then, using least squares (Menke, 1989), we compute linear relations. The data used and results are presented in Fig. 1 and Table 1, along with estimated errors and correlation coefficients.

Afterwards, combining all the available information, we remove the influence of any clusters following the methodology described by Reasenberg (1985), in order to maintain the assumption that the occurrence of earthquakes follows a Poisson distribution. Once we obtain a definitive catalogue, we compute Gutenberg-Richter laws after evaluating the appropriate time window for completeness of each magnitude range (Stepp, 1971, 1973), as done in previous works in Chile (Labbe, 1976; Labbe and Saragoni, 1976). 

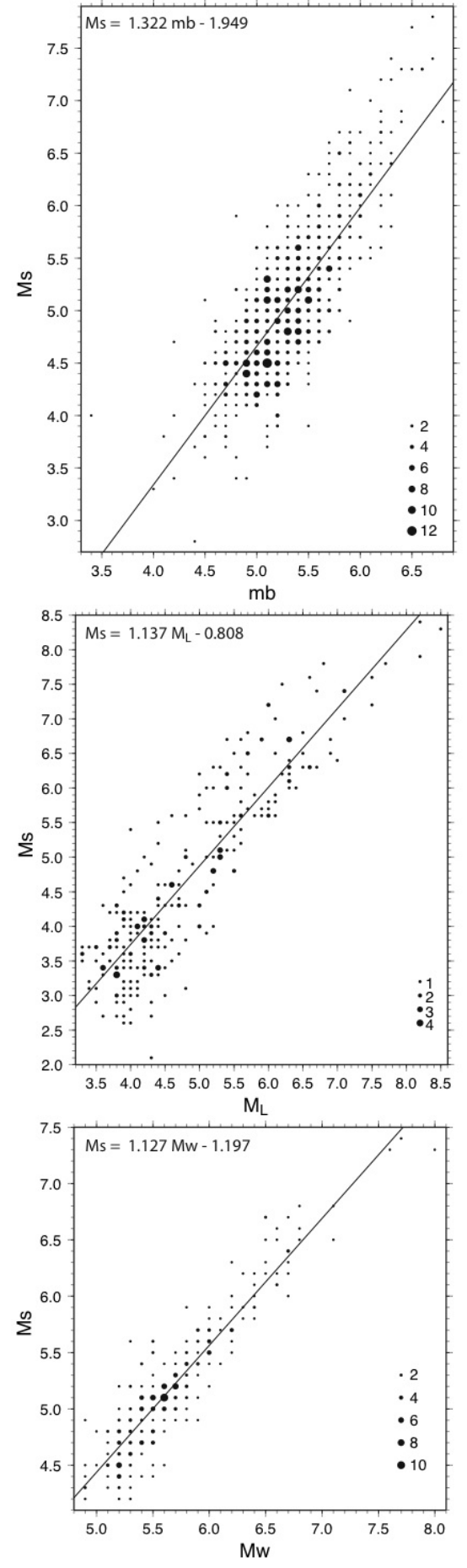

Fig. 1. Linear relation between different magnitudes, from top to bottom is presented $M_{S}$ as a function of $\mathrm{mb}, M_{L}$, and $M_{w}$, respectively; continuous lines represent the least squares fits with relation shown in the upper left corner. Each dot represents an observed pair, where the size is proportional to the number of observations of that pair (see scale in lower right side of each plot).
Table 1. Linear relations $M_{s}=\alpha \cdot \operatorname{mag}+\beta \pm \sigma$ for different magnitudes used in Chile (see text for details); $\sigma$ corresponds to the estimated error and $r$ the correlation coefficient.

\begin{tabular}{lrrrrr}
\hline & & & & & $\begin{array}{r}\text { Number of } \\
\text { Observations }\end{array}$ \\
\hline$M_{S}$ vs. & $\alpha$ & $\beta$ & $\sigma$ & $r$ & 730 \\
$\mathrm{mag}=\mathrm{mb}$ & 1.322 & -1.949 & 0.1914 & 0.7914 & 268 \\
$\mathrm{mag}=M_{L}$ & 1.137 & -0.808 & 0.3625 & 0.8919 & 258 \\
$\mathrm{mag}=M_{w}$ & 1.127 & -1.197 & 0.0559 & 0.9242 & \\
\hline
\end{tabular}

In this study, we use the attenuation laws defined by Ruiz and Saragoni (2005) for Chilean data, representing the particular behaviour of earthquakes within an Andean subduction environment. Ruiz and Saragoni (2005) considered the differences in seismogenic source, defining a particular function for interplate, thrust earthquakes and intermediate depth, intraplate events and included information regarding the site conditions. For this work, we selected the relation defined for rock or stiff soil, mostly characterized by an average $S$-wave velocity for the upper $30 \mathrm{~m}$ between 360 and $1500 \mathrm{~m} / \mathrm{s}$. Due to the fact that seismic waves are strongly modified by surface structure (Astroza and Monge, 1989; Borcherdt, 1994; Field, 2000), the results presented here probably are overestimated for site with hard rock and under estimated for soft soils. However, Santiago and some of the most populated cities in the country are located on rock or stiff soil such as alluvial and fluvial deposits, thus the selection of this relationship tend to reproduce the hazard more accurately in areas of higher vulnerability and impact on the population.

Finally, we selected a maximum credible magnitude of $M_{s}=8.5$ for interplate, thrust earthquakes and $M_{S}=8.0$ for intermediate depth, intraplate earthquakes, as done in previous works (Romanoff, 1999; Leyton et al., 2009b).

\section{Results}

After homogenizing the magnitudes into $M_{S}$ and removing the effect of clusters, we can describe the seismic productivity using well-known methods (Gutenberg and Richter, 1944). We compute the productivity Gutenberg-Richter laws $\left(\log (\mathrm{N})=a-b M_{s}\right)$ using the maximum likelihood method, as defined by Page (1968) and later extended to unequal observational periods by Weichert (1980); in this study, the minimum magnitude for completeness was defined using the maximum curvature (Wiemer and Wyss, 2000). The results are presented in Table 2 (and Fig. 3), for all the seismogenic sources considered in this study (Z1 to Z7). Note that the $a$-value depends on the area while the b-value is function of the relative number of small to large magnitudes. From Table 2, we can see that in general, interplate, thrust seismogenic sources ( $\mathrm{Z} 1$ to $\mathrm{Z3}$ ) have a larger productivity than intraplate, intermediate depth sources (Z4 to Z7), except for Z5 


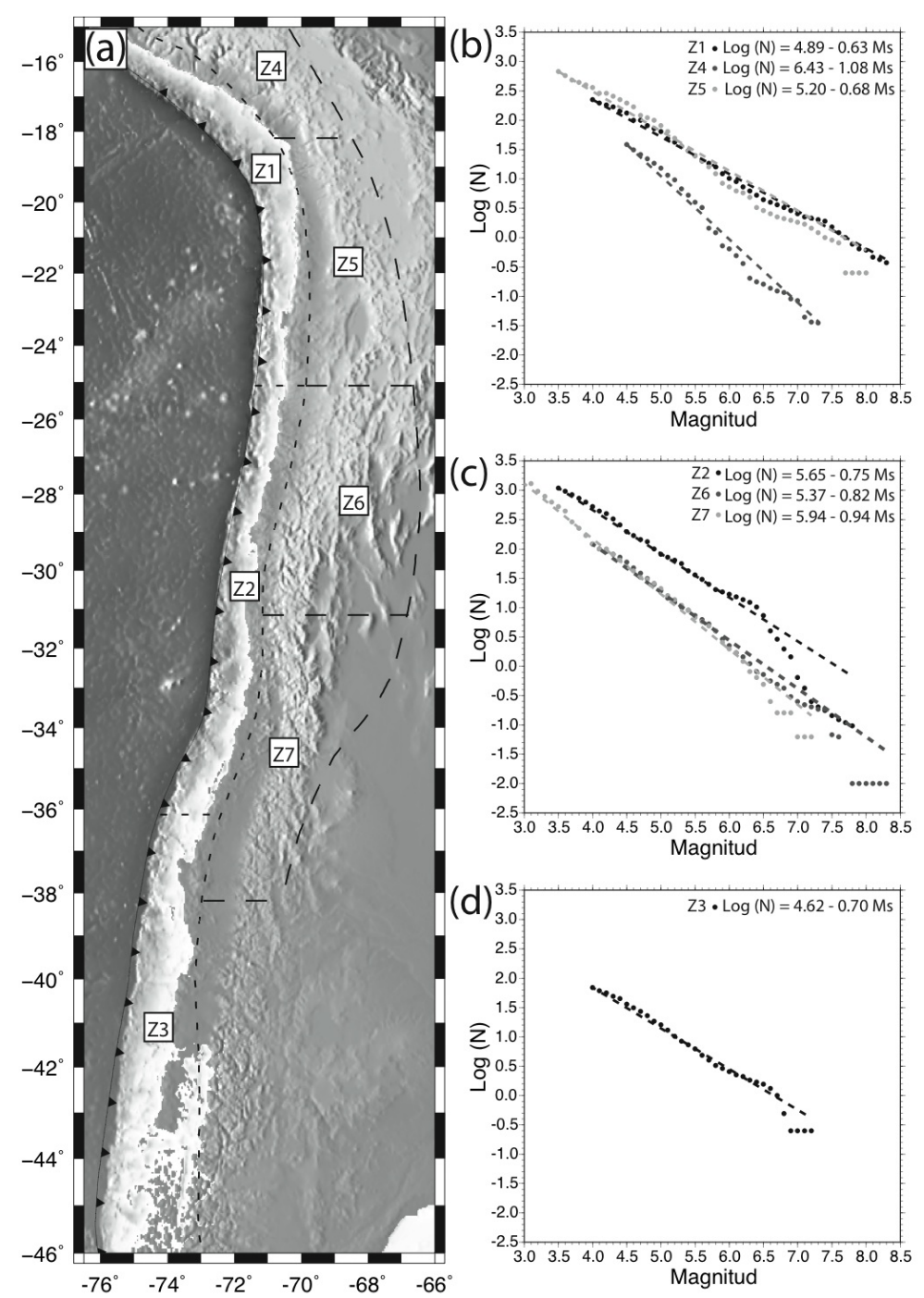

Fig. 2. (a) Topographic map with location of seven zones used in this study; $Z 1$ to $Z 3$ correspond to interplate, thrust seismogenic sources while Z4 to Z7 are intermediate depth, intraplate seismogenic sources (modified from Martin, 1990). (b-d) Gutenberg-Richter laws for all zones considered, dashed lines represent results from maximum likelihood method (see text for details); dots represent data points for each source, according to the colour code in upper-right corner. For each subplot: (b) sources Z1, Z4, and Z5, (c) source Z2, Z6, and Z7, (d) source Z3.

that presents values similar to Z1. This large seismic productivity has been recently reported (Sasorova and Levin, 2008), having a strong influence in the results.

Following the methodology defined by Algermissen and Perkins (1976), we compute the expected horizontal peak ground acceleration with a $10 \%$ probability of being exceeded in 50 years, equivalent to a return period of 475 years. The results are presented in Fig. 3, from where we can see that, in general, the largest peak accelerations are expected in the coast (ranging from 0.6 to $1.0 \mathrm{~g}$ ), while in the Andes Mountains, the PGA is almost halved $(0.4$ to $0.5 \mathrm{~g})$. At a second glance, we find that the Southern part of the country $\left(\sim 36^{\circ} \mathrm{S}\right.$ to $\left.46^{\circ} \mathrm{S}\right)$ present the lowest values of expected PGA, probably caused by the fact that this area corresponds to the rupture area of the Valdivia 1960 earthquake, region with very long return periods (over 200 years for earthquakes with magnitude $\geq 8.5$, according to the Gutenberg-Richter laws presented in this study and recently estimated to $\sim 285$ years, Cisternas et al., 2005, or ranging between 500 to 2000 years, Moernaut et al., 2007). On the other hand, for latitudes between $18^{\circ} \mathrm{S}$ and $25^{\circ} \mathrm{S}$, we found PGA values over $0.8 \mathrm{~g}$, decreasing below this value at more than $100 \mathrm{~km}$ from the coast; this may be produced by the large seismic productivity ( $a$-value of the Gutenberg-Richter law) found in zone Z5. 


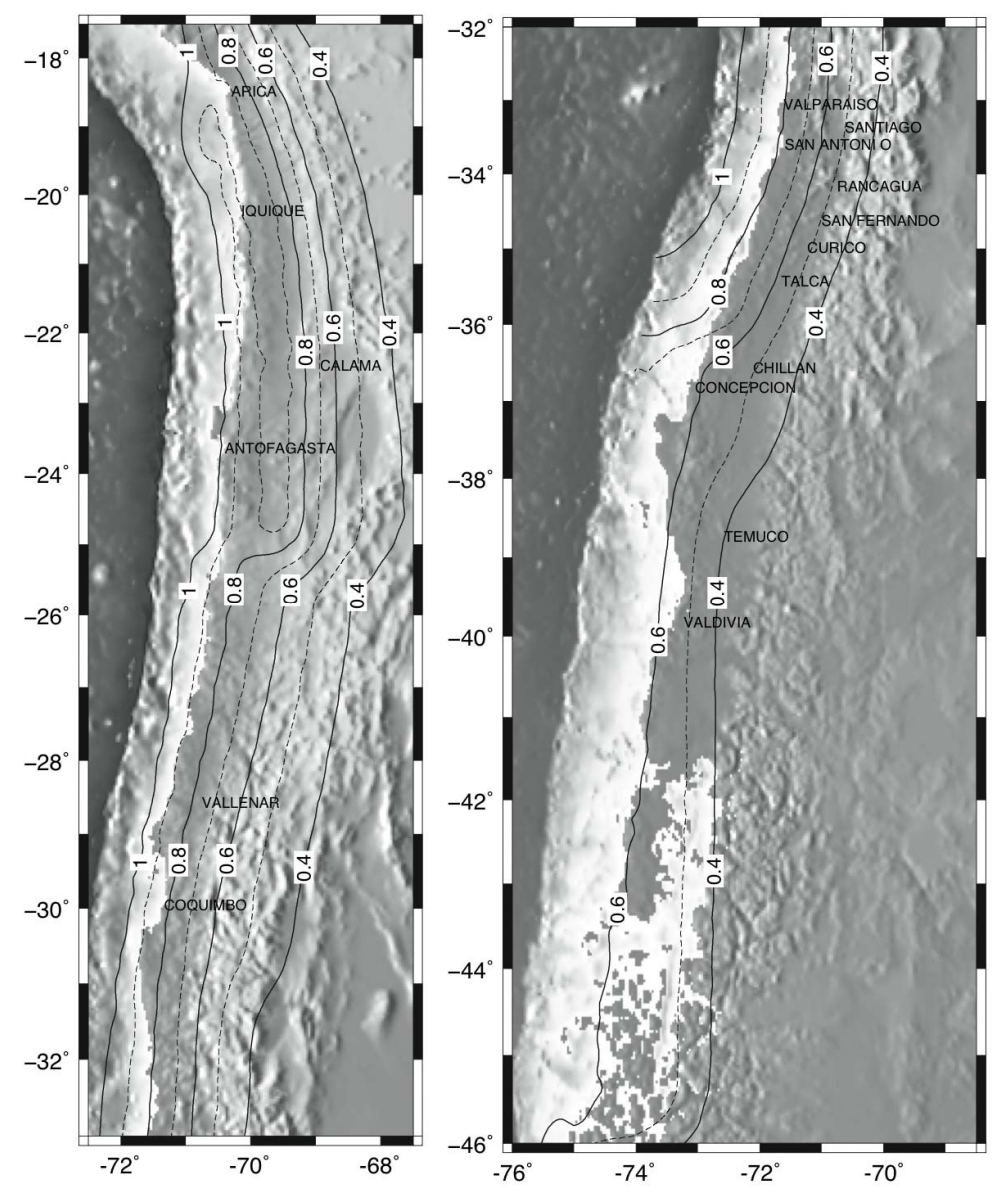

Fig. 3. Topographic map presenting contours with the horizontal peak ground acceleration (PGA), in terms of gravity acceleration (g), with a probability of $10 \%$ of being exceeded in 50 years (corresponding to 475 years return period).

Table 2. Gutenberg-Richter laws $\left(\log \mathrm{N}=a-b M_{S}\right)$ for the seismogenic zones used in this study (Z1 to Z7).

\begin{tabular}{lrr}
\hline Zone & $a$ & $b$ \\
\hline Z1 & 4.89 & 0.63 \\
Z2 & 5.65 & 0.75 \\
Z3 & 4.62 & 0.70 \\
Z4 & 6.43 & 1.08 \\
Z5 & 5.20 & 0.68 \\
Z6 & 5.37 & 0.82 \\
Z7 & 5.94 & 0.94 \\
\hline
\end{tabular}

\section{Conclusions}

In the present study we compute preliminary estimations of the seismic hazard in Chile (from Arica to Taitao Peninsula, in other words, from $18^{\circ} \mathrm{S}$ to $45^{\circ} \mathrm{S}$ ), considering only the two main seismogenic sources: interplate, thrust earthquakes and intermediate depth, intraplate earthquakes. For this purpose, we describe each seismogenic source separately to properly incorporate its the effect, update estimations of Gutenberg-Richter laws, and use attenuation laws specifically defined for the study region. We found that, in general, the expected horizontal peak ground acceleration is larger on the coast (reaching values from 0.6 to $1.0 \mathrm{~g}$ ), while by the Andes Mountains values are smaller (ranging from 0.4 to $0.6 \mathrm{~g}$ ). Unexpectedly large values are found in the Northern part of Chile (PGA over $0.8 \mathrm{~g}$ ) due to the high seismic productivity found in that region (see Table 2 and Fig. 2), while low values in the Southern part (PGA lower that $0.6 \mathrm{~g}$ ) are caused by the characteristic long return periods of the large to very large earthquakes produced there. However, the use of Gutenberg-Richter law to predict the behaviour of mega-earthquakes (such as Valdivia 1960) might lead to unexpectedly high errors and other recurrence models could be more suitable (e.g., a hybrid recurrence model, as shown in Wu et al., 1995). Even more, these computations need to include information from a third important seismogenic source present in Chile (crustal earthquakes), improve the separation of interplate, thrust and intermediate depth, intraplate 
earthquakes according to recent findings of the seismic coupling depth, and probably redefine new seismogenic zones according to recent data, in order to produce final results of the seismic hazard assessment in Chile.

The results presented here were computed using attenuation relations specially defined for Chilean earthquakes, separating for interplate, thrust events and intermediate depth, intraplate events, for site on rock or stiff rock; estimations of any specific location must be studied independently. More over, the results presented in this work do not include the effect of crustal seismicity; hence, they should be appropriately modified to include these sources in order to be eligible for a more extensive analysis. Nevertheless, the present study updates the seismic hazard estimations in Chile for the two most important seismogenic sources, enabling a better prevention for this kind of phenomena.

Acknowledgements. The authors wish to thank E. Kausel, S. Barrientos, J. Campos, and M. Astroza for their continuous support and encouraging discussions. Comments made by C. Lomnitz, an anonymous reviewer, and R. I. Tilling greatly improved this work. This paper was funded by Fondecyt 11070030 and Millennium Nucleus in Seismotectonics and Seismic Hazard. Figures were made using GMT (Wessel and Smith, 1991).

Edited by: B. Tilling

Reviewed by: C. Lomnitz and another anonymous referee

\section{References}

Algermissen, S. T. and D. M. Perkins: A probabilistic estimate of maximum acceleration in rock in the contiguous Unites State, US Geological Survey Open-File Report, 1976..

Algermissen, S. T., Kausel, E., Hanson, S., and Thenhaus, P. C.: Earthquake hazard in Chile, Rev. Geofísica, 37, 195-218, $1992 .$.

Alvarez, M., Fischer, T., De la Llera, J. C., and Ridell, R.: Un modelo integrado para el análisis del riesgo sísmico en edificios, VIII Jornadas Chilenas de Sismología e Ingeniería Antisísmica, Valparaíso, Chile, 2002.

Araya, P.: Catálogo actualizado de intensidades sísmicas para Chile, Dissertation for Civil Engineering, Universidad de Chile, Santiago, 2007.

Askew, B. and Algermissen, S. T.: Proyecto SISRA, Programa para la Mitigación de los Efectos de los Terremotos en la Región, 1985.

Astiz, L., Lay, T., and Kanamori, H.: Large intermediate-depth earthquakes and the subduction process, Phys. Earth Planet. Int., 53, 80-166, 1988.

Astroza, M. and Monge, J.: Aumento de intensidades según las características geológicas del los suelos de fundación, sismo del 3 de marzo de 1985, Anales de la Universidad de Chile, Universidad de Chile, Santiago, Chile, 1989.

Astroza, M., Moya, A., and Sanhueza, S.: Estudio comparativo de los efectos de los terremotos de Chillán de 1939 y de Talca de 1928, VIII Jornadas Chilenas de Sismología e Ingeniería Antisísmica, Valparaíso, Chile, 2002.

Astroza, M., Sandoval, M., and Kausel, E.: Estudio comparativo de los efectos de los sismos chilenos de subducción del tipo in- traplaca de profundidad intermedia, IX Jornadas de Sismología e Ingeniería Antisísmica, Concepción, Chile, 2005.

Barrientos, S.: Regionalización sísmica de Chile, Dissertation for MSc Geophysics, Universidad de Chile, Santiago, Chile, 1980.

Barrientos, S.: Earthquakes in Chile, in: The Geology of Chile, edited by: Moreno, T. and Gibbons, W., Geological Society of London, 263-287, 2007.

Borcherdt, R. D.: Estimates of site-dependent response spectra for design (methodology and justification), Earthquake Spectra, 10, 617-653, 1994.

Castaños, H. and Lomnitz, C.: PSHA: is it science?, Eng. Geol., 66, 315-317, 2002.

Cisternas, M., Atwater, B. F., Torrejón, F., Sawai, Y., Machuca, G., Lagos, M., Eipert, A., Youlton, C., Salgado, I., Kamataki, T., Shishikura, M., Rajedran, C. P., Malik, J. K., Rizal, Y., and Husni, M.: Predecessors of the giant 1960 Chile earthquake, Nature, 437, 404-407, 2005.

Cornell, C. A.: Engineering seismic risk analysis, B. Seism. Soc. Am., 58, 1583-1606, 1968.

Cornell, C. A. and Winterstein, S. R.: Temporal and magnitude dependence in earthquake recurrence models, B. Seism. Soc. Am., 93, 314-331, 1988.

Field, E. H.: A modified ground-motion attenuation relationship for Southern California that accounts for detailed site classification and a basin-depth effect, B. Seismol. Soc. Am., 90, S209-S221, 2000.

García, D., Singh, S. K., Herráiz, M., Pacheco, F. J., and Ordaz, M.: Inslab earthquakes of central Mexico: $Q$, source spectra, and stress drop, B. Seismol. Soc. Am., 94, 789-802, 2005.

Greve, F.: Determinación del coeficiente de seguridad antisísmico para diferentes zonas de Chile, Anales de la Facultad de Ciencias Físicas y Matemáticas, Universidad de Chile, Santiago, Chile, 1948.

Gudmundsson, O. and Sambridge, M.: A regionalized upper mantle (RUM) seismic model, J. Geophys. Res., B4, 7121-7136, 1998.

Gutenberg, B. and Richter, C.: Frequency of earthquakes in California, B. Seism. Soc. Am., 34, 185-188, 1944.

ISC, International Seismological Centre: On-line Bulletin, online available at: http://www.isc.ac.uk, Internatl. Seis. Cent., Thatcham, UK, 2001.

Kanamori, H.: Rupture process of subduction-zone earthquakes, Annu. Rev. Earth Planet. Sci., 14, 293-322, 1986.

Kausel, E. and Campos, J.: The M=8.0 tensional earthquake of December 9, 1950 of northern Chile and its relation to the seismic potential of the region, Phys.Earth Planet. Int., 72, 220-235, 1992.

Khazaradze, G. and Klotz, J.: Short and long-term effects of GPS measured crustal deformation rates along the South-Central Andes, J. Geophys. Res., 108(B4), 1-13, 2003.

Khintchine, A. J.: Mathematical models in the theory of queuing, Griffin, London, 1960.

Labbe, J. C.: Relaciones macrosísmicas para la evaluación del riesgo sísmico en Chile y California, Dissertation for Civil Engineering, Universidad de Chile, Sanitago, Chile, 1976.

Labbe, J. C. and Saragoni, G. R.: Sismicidad de Chile, Publicación SES I 7/76, Sección Estructuras, Depto, Obras Civiles, Fac. de Ciencias Físicas y Matemáticas, Universidad de Chile, Santiago, Chile, 1976.

Leyton, F., Ruiz, J., Campos, J., and Kausel, E.: Intraplate and inter- 
plate earthquakes in Chilean subduction zone: A theoretical and observational comparison, Phys. Earth Planet. Int., 175, 37-46, 2009a.

Leyton, F., Ruiz, S., and Sepúlveda, S.: Reevaluación del Peligro Sísmico en Chile Central, Andean Geology, in press, 2009 b.

Lomnitz, C.: An earthquake risk map of Chile, paper presented at 4th World Conference on Earthquake Eng, 1969.

Martin, A.: Hacia una nueva regionalización y cálculo del peligro sísmico en Chile, Dissertation for Civil Engineering, Universidad de Chile, Santiago, Chile, 1990.

Mattews, M. V., Ellsworth, W. L., and Reasenberg, P.: A Brownian model for recurrent earthquakes, B. Seism. Soc. Am., 92, 22332250, 2002.

Menke, W.: Geophysical Data Analysis: Discrete Inverse Theory, Academic Press, New York, 1989.

Moernaut, J., De Batist, M., Charlet, F., Heirman, K., Chapron, E., Pino, M., Brümmer, R., and Urrutia, R.: Giant earthquakes in Shouth-Central Chile revelead by Holocene mass-wasting events in Lake Puyehue, Sediment. Geol., 195, 239-256, 2007.

Musson, R. M. W., Toro, G. R., Coppersmith, K. J., Bommer, J. J., Deichmann, N., Bungum, H., Cotton, F., Scherbaum, F., Slejko, D., and Abrahamson, N. A.: Evaluating hazard results for Switzerland and how not to do it: A discussion of "Problems in the application of the SSHAC probability method for assessing earthquake hazards at Swiss nuclear power plants", edited by: Klügel, J.-U., Eng. Geol., 82, 43-55, 2005.

National Earthquake Information Center, NEIC: http://earthquake. usgs.gov/, edited by: USGS, 2009.

Page, R.: Aftershocks and microaftershocks, B. Seism. Soc. Am., 58, 1131-1168, 1968.

Reasenberg, P.: Second-order moment of central California seismicity, 1969-1982, B. Seism. Soc. Am., 90(B7), 5479-5495, 1985.

Romanoff, F.: Estudio del Peligro Sísmico en la Región Metropolitana, Dissertation for Civil Engineering, Universidad de Chile, Santiago, Chile, 1999.

Ruff, L. and Kanamori, H.: Seismicity and the subduction process, Phys. Earth Planet. Int., 23, 240-252, 1980.

Ruiz, S. and Saragoni, G. R.: Fórmulas de atenuación para la subducción de Chile considerando los dos mecanismos principales de sismogenesis y los efectos del suelo, IX Jornadas Chilenas de Sismología e Ingeniería Antisísmica, Concepción, Chile, 2005.

Saragoni, G. R., Astroza, M., and Ruiz, S.: Comparative study of subduction earthquake ground motion of north, central and south America, paper presented at 13th World Conference on Earthquake Eng., Vancouver, Canada, 2004.
Sasorova, E. and Levin, B.: Peculiarity of the spatial and temporal distributions of seismic events in Andes (South America). paper presented at 4th Alexander von Humboldt International Conference, The Andes: Challenge for Geosciences, Santiago, Chile, 2008.

Scholz, C.: The Mechanics of Earthquakes and Faulting, Cambridge University Press, Cambridge, UK, 2002.

Schwartz, D. P. and Coppersmith, K. J.: Fault behaviour and characteristic earthquake: examples from the Wasatch and San Andreas fault zones, J. Geophys. Res., 89, 5681-5698, 1984.

Singh, S. K., Ordaz, M., Alcántara, L., Shapiro, N., Kostoglodov, V., Pacheco, J. F., Alcocer, S., Guitiérrez, C., Quass, R., Mikumo, T., and Ovando, E.: The Oaxaca earthquake of 30 septembre $1999\left(M_{w}=7.5\right)$ : A normal-fault event in the subducted Cocos Plate, Seism. Res. Lett., 71, 67-78, 2000.

Stepp, J. C.: An investigation on earthquake risk in the Puget Sound area by use of Type I Distribution of largest extremes, Dissertation for Ph. D., Pennsylvania State University, 1971.

Stepp, J. C.: Analysis of completeness of the earthquake sample in the Puget Sound area, NOAA Technical Report ERL 267-ESL 30, US Department of Commerce, Boulder, Colorado, 1973.

Uyeda, S. and Kanamori, H.: Back-arc opening and the mode of subduction, J. Geophys. Res., 80, 195-222, 1979.

Villablanca, R. and Riddell, R.: Evaluación del riesgo sísmico en Chile, DIE, Departamento de Ingeniería Estructural, Universidad Católica de Chile, Santiago, Chile, 153 pp., 1985.

Wang, Z.-M., Woolery, E. W., Shi, B.-P., and Kiefer, J. D.: Communicating with uncertainty: A critical issue with probabilistic seismic hazrd analysis, EOS Trans. AGU, 84, 501-508, 2003.

Weichert, D. H.: Estiamtion of the earthquake recurrence parameters for unequal observation periods for different magnitudes, B. Seism. Soc. Am., 70, 1337-1346, 1980.

Wesnousky, S. G.: The Gutenberg-Richter or Characteristic earthquake distribution, which is it?, B. Seism. Soc. Am., 84, 19401959, 1994.

Wessel, P. and Smith, W. H. F.: Free software helps map and display data, EOS Trans. AGU, 72, 445-446, 1991.

Wiemer, S. and Wyss, M.: Minimum magnitude of complete reportting en earthquake catalogs: examples from Alaska, the Western United States, and Japan., B. Seism. Soc. Am., 90, 859-869, 2000.

Wu, S.-C., Cornell, C. A., and Winterstein, S. R.: A hybrid recurrence model and its application on seismic hazard results, B. Seism. Soc. Am., 85, 1-16, 1995. 